\title{
Comparative Study of Two Conventional Methods Used for Coliform Enumeration from Port Harcourt Waters
}

\author{
Prince Chinonso Nnadozie \\ Department of Microbiology, Faculty of Sciences, University of Port Harcourt, Port Harcourt, Nigeria \\ Email: princemakat@yahoo.co.uk
}

Received 5 March 2016; accepted 20 March 2016; published 23 March 2016

Copyright (C) 2016 by author and OALib.

This work is licensed under the Creative Commons Attribution International License (CC BY). http://creativecommons.org/licenses/by/4.0/

(c) †) Open Access

\section{Abstract}

This study compares two conventional methods: Membrane Filtration (MF) and Multiple Tube Fermentation (MTF) used in the analysis of two Port Harcourt natural water sources, Abonnema Wharf (A) and Tourist Beach (B). However, these methods are generally used in the determination of the sanitary condition of the waters and its suitability for general use. It is observed from the study that the MF gives a more reliable and precised data than that of the MTF which is time consuming, labour intensive and less precised. Bacterial isolates such as the Enterococcus faecalis not present with the use of MF method may be as a result of seasonal changes, spatial distribution of organism, and varying degree of human/animal and industrial activities/influence on the ecosystem. Studies on the effects of physiological stress especially stress by chlorination should be carried out on the waters in order to substantiate the effectiveness of each method and also identify the best conventional method to be applied during analysis of water.

\section{Keywords}

Membrane Filtration, Most Probable Number, Coliforms

Subject Areas: Environmental Sciences, Microbiology

\section{Introduction}

Novel protocols used in the detection and characterization of microorganisms have helped to advance research in the field of Microbiology. Although, rapid methods (molecular and immunological based) for microbial identification and characterization have led to appreciable remarkable progress in science by its peculiar fast throughputs of results and accuracy (i.e., its sensitivity, specificity and limit of detection), the International Organization for Standardization (ISO) accredited conventional methods are very important in that they are rela- 
tively easy to use and cost effective. Both the Multiple Tube Fermentation (Most Probable Number, MPN) and Membrane Filtration (MF) methods for Coliform enumeration are permitted [1] [2].

The analyses of water samples, for enumeration of Coliforms, require two major convectional techniques also known as culture-dependent methods: the MF and the MPN techniques. The screening of the water samples are important because water as a universal solvent is an essential requirement for all forms of life, be it prokaryotes or eukaryotes. Roohul-Amin et al. [3] estimated that over 250 million cases of waterborne diseases are reported worldwide and over 25 million deaths are blamed due to waterborne diseases. It is therefore necessary that the supply of water for human consumption should be of good quality-free from disease causing micro-organisms, harmful chemicals, poisonous elements and other toxic substances.

The MF technique which was developed for routine examination of water has the advantages of being able to examine large volumes of water than with MPN [4], as well as having a high precision and reliability and requiring significantly reduced time, labour, equipment, space, and materials. But it cannot be used on highly turbid water samples (see Table 1). It has also been observed that inhibitory materials (particulate matter) in the water can interfere with colony development when they stick to the filters. Also, high population of bacteria other than Coliforms may cause confluent growth.

In the MPN method, there is statistical bias and lack of precision inherent in it [5]. Thus, it gives only a statistical estimate of the number of bacteria that would give the observed result; not an actual count of the bacteria present despite the longer time it takes to produce results [4]. However, the MF is not feasible, such as with turbid or grossly contaminated water, the MPN procedure is found to be useful.

The comparability of the MPN method with the MF method in unchlorinated and natural waters by so many researchers has favoured the use of MF to MPN. Reports have showed that chlorine-stressed Coliforms are not as efficiently enumerated with the MF method as with the MPN method [6]-[8]. Contrary to this stance, Tobin et $a l$. [2] have demonstrated that the MF method gives results equivalent to those given by the MPN method even with chlorine-stressed Coliforms.

\section{Aims/Objectives}

To compare two conventional methods used in the enumeration of Coliforms from natural water samples obtained from Abonnema Wharf (A) and Tourist Beach (B) in Port Harcourt.

\section{Materials and Methods}

The enumeration of faecal and total Coliforms from Abonnema Wharf (A) and Tourist Beach (B) waters in Port Harcourt involves aseptic collection of water samples from the two sample stations. A total of eight water samples were collected from eight sites $\left(A_{0}, A_{1}, A_{2}, A_{3}, B_{0}, B_{1}, B_{2}\right.$ and $\left.B_{3}\right)$ and bacteriologically analysed via MPN method as described by Abu and Nnadozie [10], and another total of eight water samples were collected with a sterile screw-capped glass bottles from the same sites as described by Nnadozie [11].

Table 1. Comparison of coliform analysis methods.

\begin{tabular}{cc}
\hline Multiple Tube Fermentation Method & Membrane Filter Method \\
\hline More labour intensive & More rapid: quantitative results in about 18 hours \\
Requires more culture medium & Less labour intensive \\
Requires more glassware & Requires less culture medium \\
More sensitive & Requires less glassware \\
Low precision & Less sensitive \\
Difficult to use in the field & High precision \\
Applicable to all types of water & Can be adapted for field use \\
Not applicable to turbid waters & Cost of consumables is high in many Countries \\
May give better recovery of stressed or damaged organisms &
\end{tabular}

Source: [9]. 


\subsection{Membrane Filtration Procedure}

In the Membrane filtration (MF) procedure membrane filter absorbent pads were each placed inside a sterile Petri-dish, and saturated with $2 \mathrm{ml}$ of Endo agar lactose-based medium. $100 \mathrm{ml}$ of water sample, each for the sample stations, was filtered through a membrane filter $(0.45 \mu \mathrm{m}$ pore size). After which the filters (bearing the residue) was placed on the medium with aid of sterile forceps. The Petri dishes were inverted and incubated for 24 - 48 hours at $35^{\circ} \mathrm{C} \pm 0.5^{\circ} \mathrm{C}$ for total Coliform and at $44^{\circ} \mathrm{C} \pm 0.5^{\circ} \mathrm{C}$ for faecal Coliform. After 48 hours of incubation, colonies (20 - 200) were observed and counted.

The Coliform density of the water samples are based upon the membrane filter count within the 20 - 200 Coliform colony range and calculated thus [12]: Total Coliform or Faecal Coliform per $100 \mathrm{ml}$ is equal to the ratio of the average Coliform colonies counted at $35^{\circ} \mathrm{C}$ or $44.5^{\circ} \mathrm{C}$ respectively to the volume of water samples filtered (in mililiter), and multiplied by 100.

\subsection{Multiple Tube Fermentation Method}

The method as described by Abu and Nnadozie [10] was adopted in the enumeration of coliforms. This method involves the enumeration of Coliform (bacteria) from water samples. The use of 5 test-tubes containing a lactose-based media Lauryl Tryptose Broth (LTB) with Durham's gas tubes is aimed at monitoring presumptively the fermentation of media by Coliforms and observing the acidification and gas production during growth in the lactose broth at either $35^{\circ} \mathrm{C}$ or $44^{\circ} \mathrm{C} \pm 0.5^{\circ} \mathrm{C}$ for $24-48$ hours. The growth was confirmed by subculturing from the fermentation tubes on Eosine-Methylene Blue (EMB) agar plates, MacConkey agar plates and Brilliant Green Lactose Broth (BGLB). The presence of gas and acid in the lactose based broth within 48 hours at $35^{\circ} \mathrm{C}$ or $44.5^{\circ} \mathrm{C}$ constitutes a positive confirmation test. Positive cultures grown on EMB plates with metallic sheen colonies confirm the presence of faecal Coliform (specifically Escherichia coli). The MTF method for the Coliform check is completed when a lactose-based medium and agar slant (nutrient agar slope) were inoculated with positive cultures from the confirmed culture wares. The growth of Gram's negative rods and non-spore forming bacteria on the agar slant, and presence of gas production in the lactose medium constitutes a positive completed test.

\section{Results/Discussion}

The results from both methods showed the presence of faecal Coliforms in the two water bodies. Both methods supported the null hypothesis indicating no significant difference between the aquatic systems. The water indices contradict the World Health Organizations (WHO) standards for potable water. Tourist Beach water (A) contains the highest faecal Coliform than Abonnema Wharf water (B). This implies that B is more polluted than A.

Abu and Nnadozie [10] have showed that by MTF procedure, it was revealed that the faecal Coliform count is between 11- >17 MPN/100 ml and 26 - 46 MPN/100ml in A and B respectively; whereas through the MF method, Nnadozie [11] reported that it was $2.25 \times 10^{1}-1.48 \times 10^{2} \mathrm{CFU} / 100 \mathrm{ml}$ and $7.30 \times 10^{1}-1.88 \times 10^{2}$ CFU/100 ml microbial loads respectively. The total Coliform counts via MF in the A and B ranges from $4.05 \times$ $10^{1}-1.77 \times 10^{2} \mathrm{CFU} / 100 \mathrm{ml}$ and $5.60 \times 10^{1}-1.96 \times 10^{2} \mathrm{CFU} / 100 \mathrm{ml}$ [11] respectively. Eleven (11) bacterial species were isolated through MPN method [10]; while through the MF technique, a total of twelve (12) bacterial genera were isolated by Nnadozie [11] and mostly, which are of great public health concern, and are the cause of enteric diseases in humans.

The use of MF method revealed the presence of Vibrio spp. and Serratia spp. which were not found through the use of MTF method. This is because unlike the MTF method, the MF method allows an appreciable volume of water to be filtered; and it has been recommended for its accuracy and speed of result [13]. The presence of Enterococcus faecalis which was found only at site $\mathrm{B}_{3}$ of Tourist Beach by MPN method may be as a result of seasonal changes, spatial distribution of bacteria, and varying degree of human/animal and industrial activities/ influence on the ecosystem as suggested by Nnadozie [11]. The design of the study is limited to bacteriological analysis of water samples. With the exception of $\mathrm{pH}$, it does not cover other physico-chemical parameters such as the Dissolved Oxgyen (DO), Chemical Oxygen Demand (COD), Biochemical Oxygen Demand (BOD), Total Dissolved Solids (TDS), salinity as chloride content, etc. that could also be used in the determination of water quality. Studies on the effects of physiological stress especially stress by chlorination should be carried out on the waters in order to substantiate the effectiveness of each method and also identify the best conventional method to be applied during analysis of water (Figure 1). 


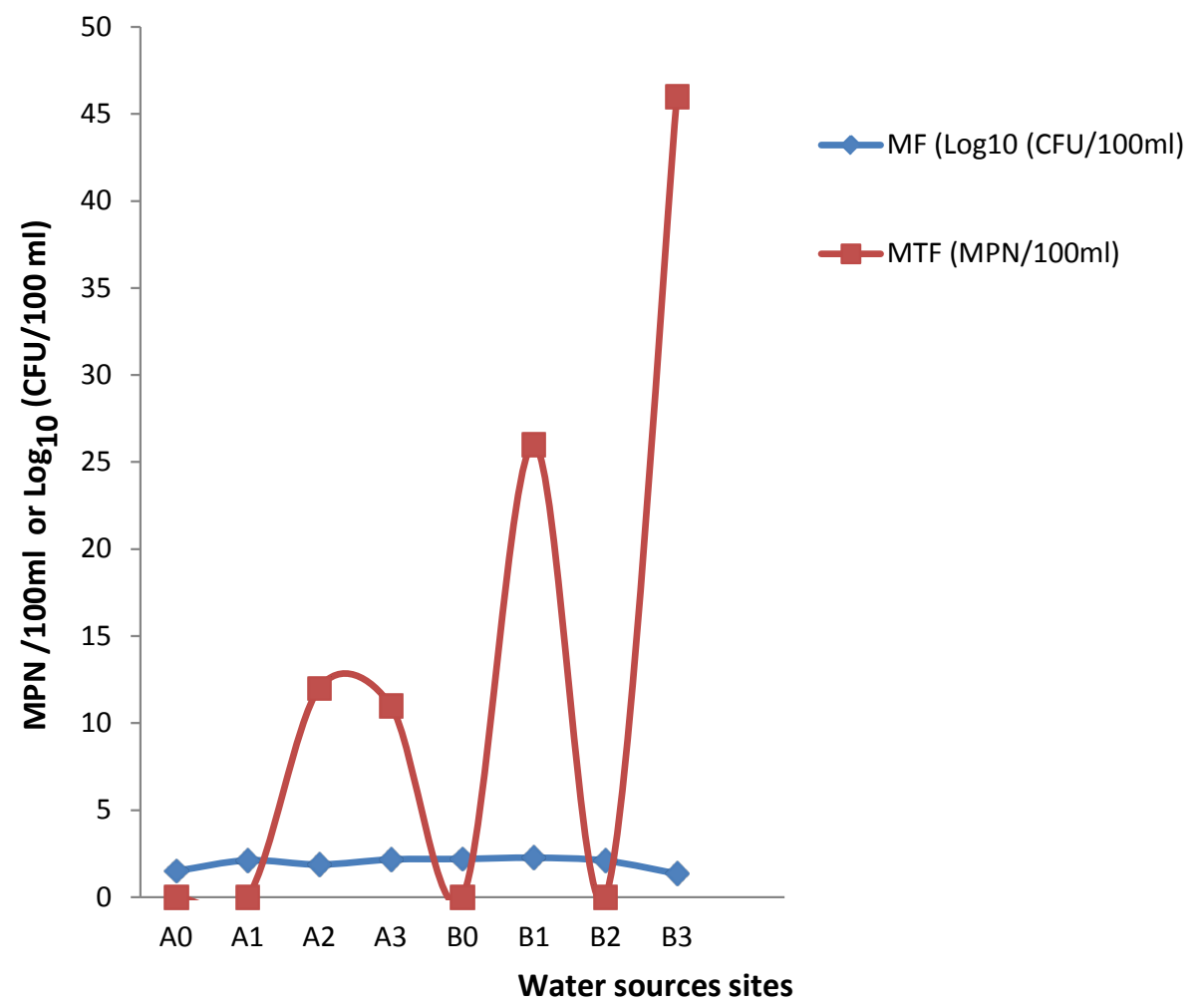

Figure 1. Graphical representation of faecal coliform counts of water samples enumerated via MF and MPN methods.

\section{Conclusion}

The analyses of natural water samples from the same source using two different methods have revealed that the MF method is the best conventional technique for water analysis as it gives the accurate microbial population present in a given sample. The varying degree of human and animal wastes, industrial activities, seasonal changes and spatial distribution of bacteria may have direct effect on the number of bacterial species present in any water system.

\section{References}

[1] APHA (1998) Standard Methods for the Examination of Water and Wastewater. 20th Edition, American Public Health Association, Washington DC.

[2] Tobin, R.S., Lomax, P. and Kushner, D.J. (1980) Comparison of Nine Brands of Membrane Filter and the Most-Probable-Number Methods for Total Coliform Enumeration in Sewage-Contaminated Drinking Water. Journal of Applied and Environmental Microbiology, 40, 186-191.

[3] Roohul-Amin, Syed, S.A., Zubair, A. and Jabar, Z.K.K. (2012) Microbial Analysis of Drinking Water and Water Distribution System in New Urban Peshawar. Current Research Journal of Biological Sciences, 4, 731-737. http://maxwellsci.com/print/crjbs/v4-731-737.pdf

[4] Ibiene, A.A. and Frank-Peterside, N. (2010) Water Quality: Physicochemical and Microbiological Standards. Essentials of Entrepreneurship, Acotec Technologies, Port Harcourt, 140-148.

[5] Hsu, S.C. and Williams, T.J. (1982) Evaluation of Factors Affection the Membrane Filters Technique for Testing Drinking Water. Applied and Environmental Microbiology, 44, 453-460.

[6] LUn, S. (1977) Evaluation of Methods for Detecting Coliforms and Fecal Streptococci in Chlorinated Secondary Sewage Effluents. In: Bordner, R.H., Frith, C.F. and Winter, J.A., Ed., Proceedings of the Symposium on the Recovery of Indicator Organisms Employing Membrane Filters, Report No. EPA-600/9-77-024, US Environmental Protection Agency, Washington DC, 113-131.

[7] Lin, S. (1973) Evaluation of Coliform Tests for Chlorinated Secondary Effluents. Journal of the Water Pollution Con- 
trol Federation, 45, 498-506.

[8] Hoffmann, D.A., Kuhns, J.H., Stewart, R.C. and Crossley, E.I. (1964) A Comparison of Membrane Filter Counts and Most Probable Numbers of Coliform in San Diego's Sewage and Receiving Waters. Journal of the Water Pollution Control Federation, 36, 109-117.

[9] Hydrology Project Training Module File (1999) 22 Coliforms as Indicator of Faecal Pollution.doc. Version 05/11/02, New Delhi, 1-46.

[10] Abu, G.O. and Nnadozie, P.C. (2015) Faecal Pollution and Enteric Bacterial Distribution in Port Harcourt Waters: A Case Study of Abonnema Wharf and Tourist Beach Waters. Int. J. of Sc. Res. and Educ., 3, 4462-4472. http://ijsae.in/ijsaeems/index.php/ijsae/article/view/967

[11] Nnadozie, P.C. (2015) The Implication of Residual Bacterial Isolates from Port Harcourt Waters. International Journal of Environmental Monitoring and Analysis, 3, 312-316. http://www.sciencepublishinggroup.com/journal/paperinfo?journalid=162

[12] US Environmental Protection Agency (1977) Manual for the Interim Certification of Laboratories Involved in Analyzing Public Drinking Water Supplies. Environmental Protection Agency publication No. 600/8-78-008. Office of Monitoring and Technical Support, US Environmental Protection Agency, Washington DC.

[13] Cheesbrough, M. (2006) District Laboratory Practice in Tropical Countries. Part 2, 2nd Edition, Cambridge University Press Publication, South Africa, 1-434. 